\title{
How has the global financial crisis affected syndicated loan terms in emerging markets? Evidence from China
}

\author{
Guglielmo Maria Caporale ${ }^{1}$ (D) | Suman $\operatorname{Lodh}^{2}$ | Monomita Nandy ${ }^{3}$
}

\author{
${ }^{1}$ Department of Economics and Finance, \\ Brunel University London, Uxbridge, UK \\ ${ }^{2}$ Business School, Middlesex University, \\ London, UK \\ ${ }^{3}$ Brunel Business School, Brunel \\ University, Guildford, UK

\section{Correspondence} \\ Guglielmo Maria Caporale, Brunel \\ University London, Uxbridge UB8 3PH \\ UK. \\ Email: guglielmo-maria.caporale@brunel. \\ ac.uk
}

JEL Classification: G21; G32; P34

\begin{abstract}
This paper examines the impact of the recent global financial crisis on the cost of debt capital (syndicated loans) in a leading emerging market, namely China, using the difference-in-differences approach. Before the crisis, China adopted banking reforms allowing the entry of foreign banks and more domestic participation in the syndicated loan market. As a result, during the crisis, the volume of syndicated loans grew steadily, in contrast to other countries. In addition, the amount of foreign syndicated loans decreased and average maturity increased compared with the pre-crisis period. Our findings provide useful information to policy makers for devising effective responses to financial crises.

KEYWORDS

China, financial crisis, loan amount, loan maturity, loan spread
\end{abstract}

\section{1 | INTRODUCTION}

During the last two decades, loans have dominated the corporate debt market in the developed economies (Drucker \& Puri, 2007); in particular, the volume of syndicated loans has increased at a very rapid rate (Ferreira \& Matos, 2012). A similar trend has been observed in emerging markets (Godlewski \& Weill, 2008), where the entry of foreign banks through syndicated loans can lower the costs of financial intermediation (Claessens \& van Horen, 2011) and reduce institutional weakness (Mishkin, 2009). However, the recent financial crisis has led to a sharp decline (by 67\%) in gross syndicated lending. Because in most cases the lead arrangers are foreign banks and financial institutions (Chui, Domanski, Kugler, \& Shek, 2010), the financial crisis that originated in the developed economies has also affected emerging markets (Doverna \& Royeb, 2014).

We are grateful to an anonymous referee for their useful comments.
Given the borrower-lender and arranger-participant relationship in syndicated loans, financial shocks can be transmitted across countries through cross-border syndicated lending (Cetorelli \& Goldberg, 2011; De Haas \& Van Horen, 2012). Moreover, foreign participation forced the firms in emerging markets to disclose more information, and consequently, the extent of monitoring increased (Berger, Hasan, \& Zhou, 2010). In fact, monitoring and opacity of firms are highly correlated with the loan contract terms (Coleman, Esho, \& Sharpe, 2006). Therefore, unlike existing studies on emerging markets only focusing on the volume of syndicated loans during the crisis (Chui et al., 2010), in this paper, we examine the impact of the financial crisis on both price and non-price contract terms of syndicated loans in China. To our knowledge, ours is the first study of this type.

The increase in international infrastructure financing has resulted in foreign banks participating more in syndicated loans to reduce the risk of default from a single bad project (Brealey, Cooper, \& Habib, 1996). Factors such as

This is an open access article under the terms of the Creative Commons Attribution License, which permits use, distribution and reproduction in any medium, provided the 
institutional weakness (Young, Tsai, Wang, Liu, \& Ahlstrom, 2014), bank-level governance, country-level governance, and previous profitability position (Beltratti \& Stulz, 2009; Berger \& Bouwman, 2013; Ivashina \& Scharfstein, 2010; Murali \& Banalieva, 2015) have all had a negative impact on syndicated loans. The performance of bank-dependent borrowers has also been affected (e.g., Chava \& Purnanandam, 2011). A "flight home effect" (Giannetti \& Laeven, 2012) is another possible explanation for the decline of the syndicated loan market.

Because China is one of the biggest economies in the world (Berger et al., 2010), it is interesting to examine the impact of the crisis on its banking system (for some of its features, see Hasan, Wachtel, \& Zhou, 2009, and Jia, 2009). In China, state controlled banks make most loan decisions expecting corporate borrowers to perform poorly (Baileya, Huanga, \& Yanga, 2011), and therefore, syndicated loans are the most popular source of corporate finance (Pessarossi \& Weill, 2013). The syndicates with lead arrangers from China have increased the loan amount even during the global financial crisis (Chui et al., 2010). However, it remains to be seen how the crisis has affected the cost of such loans and, in particular, how the syndicated loan terms with foreign arrangers compare to those with domestic arrangers.

Banks usually diversify their portfolio (Berger et al., 2010), avoid single-name exposure, diversify their income sources by incorporating fee income as lead arranger, and participate in syndicated loans to address the problems associated with origination capabilities (Godlewski \& Weill, 2008). Borrowers also benefit from syndicated loans as larger amounts (Godlewski \& Weill, 2008) can be arranged very quickly (Altunbas \& Gadanecz, 2004); therefore, other debt markets have almost disappeared in China (Pessarossi \& Weill, 2013).

The existing literature on syndicated loans documents agency conflicts arising from the lead arrangers having an information advantage over other participants (Godlewski \& Weill, 2008; Strahan, 1999). In addition, there is a moral hazard problem as a higher number of participants leads to less monitoring by banks (Pennacchi, 1988). The agency problem persisted in China during the crisis owing to information asymmetries and poor accounting disclosure systems.

Our empirical approach uses a difference-in-differences method to analyse data on 644 non-financial Chinese firms during the period 2000-2012. We find that foreign lead arrangers tend to attract more lead arrangers in a single syndicated loan to overcome the financial difficulties in their home country, and offer a lower spread than the domestic lead arrangers to be competitive in the Chinese market. However, the amount of foreign syndicated loans decreased during the crisis and their maturity shortened. Our analysis shows how the impact of the crisis was mitigated in China by agreeing appropriate syndicated loan contract terms with domestic arrangers, and has more general implications for the strategy that should be followed in emerging markets during global financial crises.

The layout of the paper is the following. Section 2 reviews the relevant literature and develops the hypotheses to be tested. Section 3 gives details of the data and the methodology. Section 4 presents the empirical results. Section 5 concludes.

\section{2 | LITERATURE REVIEW AND HYPOTHESIS DEVELOPMENT}

\section{1 | Changes in syndicated loans before and during the crisis}

Demandable debt liabilities of banks give them an incentive advantage over other intermediaries. In the last two decades, the debt market has witnessed an acceleration in the growth of syndicated loans (Dennis \& Mullineaux, 2000; Focarelli, Pozzolo, \& Casolaro, 2008) in both developed (Sufi, 2007) and emerging markets (Godlewski \& Weill, 2008). Various studies show that in most cases, the lenders in the case of syndicated loans are the banks from developed markets with excess liquidity position and recycled petrodollars (see Chui et al., 2010). An extensive survey of the banking sector by Claessens and Van Horen (2014) shows that the presence of foreign banks in emerging markets has increased rapidly due to economic integration and financial liberalization.

Some previous studies also suggest that foreign banks provide stability to host countries by improving access to credit to small- and medium-size firms and encouraging market competition (Bruno \& Hauswald, 2014). However, De Hass (2014) argues that in practice foreign banks act as a transmission channel of external shocks to emerging markets. Therefore, differences in bank capital before and during financial crisis can create difficulties for bankdependent borrowers (Chava \& Purnanandam, 2011; Demirguc-Kunt, Detragiache, \& Merrouche, 2013). This is evident from the sharp fall in the volume of global syndicated loans (Ivashina \& Scharfstein, 2010; Santos, 2011).

China has experienced an exceptional growth of syndicated loans (Chui et al., 2010; Okazaki, 2007). There are several reasons. The country has undergone a series of banking sector reforms since 2002 to become a leading market-based economy (see Ahlstrom, Young, Nair, \& Law, 2003; Okazaki, 2007; Young, Ahlstrom, Bruton, \& Rubanik, 2011), and also joined the World Trade Organization in 2001. Chui et al. (2010) find that there was 
ample supply of credit through local banks in China during the 2008-2009 financial crisis as local banks and investors maintain a business network with political parties to reduce lending risks during periods of uncertainty. In addition, typically, the lead arrangers of a syndicated loan hold the largest share of the loans (Dennis \& Mullineaux, 2000; Sufi, 2007) and thus can earn attractive fees and interest rates (Ramamurti \& Doh, 2004).

Foreign banks started their local currency business in China in December 2006. Their participation, in addition to other initiatives from the government (such as tax exemptions, strict disclosure rules, acceptance of international accounting rules, and enhancing corporate governance norms), has expanded the syndicated loan market in China. In 2008, foreign banks started withdrawing from the Chinese market, but the volume of syndicated loans arranged by domestic banks has stayed quite high, and on the whole, the syndicate loan market has grown because most of the loans originate from state-owned and joint stock commercial banks (Okazaki, 2007). Resource endowment and organizing capabilities both help Chinese firms aiming for outward internationalization (Liang, Lu, \& Wang, 2012). Domestic banks expand their activities through their networks (Bartoli, Ferri, Murroc, \& Rotondi, 2013), with borrowers preferring them because the government acts as a guarantor in most cases (Jia, 2009).

The existing literature provides evidence of the impact of syndication on loan spread, maturity, and loan amounts in other countries (Focarelli et al., 2008), and also of changes during the crisis (e.g., Ivashina \& Scharfstein, 2010; Santos, 2011; Strahan, 1999). Chui et al. (2010) show that the volume of syndicated loans increased during that period but do not examine the possible effects on loan amounts, spread, maturity, and the number of lead arrangers of syndicated loans.

\section{2 | Hypotheses development}

Firms prefer to establish relations with well-capitalized banks (Berger, DeYoung, Flannery, Lee, \& Oztekin, 2008). In a hierarchical banking structure in emerging markets, it becomes difficult to produce and transmit soft information (Stein, 2002). Liberti (2005) points out that in such a hierarchical structure, loan applications need to go through more organizational layers for approvals, and this increases information asymmetry between lead domestic arrangers and domestic participants. This asymmetry and less transparency can increase the interest rate on syndicated loans during a crisis period (see Rajan, 1992).

Recent studies also show that firms have paid more to obtain guaranteed access to liquidity during the global financial crisis (Bord \& Santos, 2014; Santos, 2011). On the other hand, foreign arrangers may suffer from "distance constraints," which leads to an increase in information and agency costs (Panizza \& Presbitero, 2014). Consequently, foreign banks with a higher capital ratio tend to charge a spread premium. In addition, during the crisis, foreign arrangers, mainly from the developed countries, have viewed emerging markets as a more financially stable market than their own economically imbalanced domestic ones. Thus, in order to offset the losses arising from non-performing loans in their home countries, they have offered lower interest rates to credit-worthy borrowers in emerging markets. The above discussion suggests the following hypothesis to test:

H1 : During the financial crisis, the interest rate in emerging markets increases less for foreign syndicated loans than for domestic syndicated loans.

Syndicated loans contribute towards financial development and stability in emerging markets (Godlewski \& Weill, 2008; Claessens \& van Horen, 2011). During the financial crisis, the financial sector in emerging markets had been growing steadily and had been strengthened by various reforms (see Okazaki, 2007). Consequently, the supply of credit remained steady in these countries during the crisis. Because of the sovereign debt crisis and the collapse of several financial institutions in 2008-2009, with the consequent crisis in confidence for the syndicated loan arrangers (mainly from developed markets), lending fell during the financial crisis (Popov \& Van Horen, 2013). Cetorelli and Goldberg (2012) show that banks in developed countries transmit the funding shocks to foreign subsidiaries. This can negatively affect the lending decisions of syndicated loans, as also reported in earlier studies such as Houston and James (1998), who show that financial shocks to banks' liabilities can create adverse selection; as a result, foreign banks can reduce their lending to emerging markets (Papov \& Udell 2012).

Moreover, foreign arrangers made more use of securitization and reduced their loan supply (Bonaccorsi di Patti \& Sette, 2012). On the other hand, Jiangli, Unal, and Yom (2008) conclude that lending relationships mattered during the Asian crisis. Previous studies show that a strong relationship between domestic banks and firms before the crisis also continued during the crisis (Bartoli et al., 2013; Chodorow-Reich, 2014). Therefore, domestic arrangers are always in a more advantageous position than foreign arrangers because of their past relationships with firms. Although the liquidity position of the domestic lead arrangers did not change during the 
crisis, the total amount of syndicated loans was affected. Thus, we test the following hypothesis:

$\mathrm{H} 2$ : During the financial crisis, foreign syndicated loans decreased in emerging markets relative to domestic syndicated loans.

Loan maturity reflects the borrower risk (Nandy \& Lodh, 2012), which is also associated with the loan spread. According to the credit quality hypothesis, lenders prefer a short maturity period for any loan because it gives them the opportunity to assess regularly the credit position of firms (Diamond, 2004). On the other hand, the trade-off hypothesis states that the loan spread increases with the maturity period (Gottesman \& Roberts, 2004). Alexandre, Bouaiss, and Refait-Alexandre (2014) provide evidence that firms managed to obtain longer maturities during the crisis when they already had a stronger lending relationship prior to it. Therefore, we argue that in emerging markets, more participation of domestic banks and poor accounting disclosure allow the arrangers to assess the credit worthiness of firms, and as a result, information asymmetry between the syndicated lenders and the borrowers is significant. In the case of syndicated loans, if there is less information asymmetry, lead arrangers tend to have a preference to hold smaller amounts (Focarelli et al., 2008). Consequently, the syndicate requires more arrangers and participants.

Moreover, if there are many lenders, the necessary monitoring decreases because the lead arrangers may exploit their informational advantage to obtain an information rent (Bruche \& Llobet, 2014). In the financial crisis period, the borrowers go through a tight screening process by foreign banks when these enter the emerging markets. This reduces the firms' opacity to some extent. But owing to the contraction in the operation of foreign banks in the Chinese credit market during the crisis, information asymmetry widened. Therefore, we test the following hypothesis:

H3 : During the financial crisis, loan maturity remained longer in emerging markets for foreign syndicated loans compared with domestic syndicated loans.

In a syndicated loan, the lead arrangers take the responsibility of originating it and share it with other financial institutions (Ivashina \& Scharfstein, 2010a). They usually keep one third of the syndicate loan and sell the rest to other syndicate investors. This may create information asymmetry between the lead arranger and the other participants, with the former possessing more information. But if the participants are not satisfied with the information about the borrowers, then the lead arranger (s) might want to share the risk with other lead arrangers in both the domestic and foreign markets. In such a situation, they may hold less than one third of the syndicated loan. On the other hand, lenders are always more inclined to give loans to firms with high profitability (Strahan, 1999); consequently, the lead arrangers may charge less interest and may arrange loans with a longer maturity to attract more borrowers for the syndicated loans.

During the financial crisis, the capital position of the foreign arrangers in their home country remained quite weak. They were attracted to emerging markets because of their financial stability. A single lead arranger cannot provide the required syndicated loan amount owing to capital inadequacy and therefore might involve other lead arrangers from the domestic and foreign markets. This leads to formulating the following hypothesis:

H4 : During the financial crisis, the number of lead arrangers for foreign syndicated loans in emerging markets increased compared with domestic syndicated loans.

\section{3 | DATA AND METHODOLOGY}

\subsection{Sample and variable description}

To test the effects of the global financial crisis on both price and non-price terms of syndicated loans, we use loan information for China from the ThomsonOne Deal database. We also match a few companies with the Worldscope and Bloomberg database to increase the number of observations. We start with all borrowers in the database and then identify the non-financial firms. In China in our sample period, which goes from 2000 to 2012 , there are 809 non-financial borrowers and 1,018 firm-bank pairs of which 749 have at least two loans.

Following the literature (e.g., Santos, 2011), the "crisis period" is defined as 2007-2009. More specifically, the fourth quarter of 2007 is taken to be the start of the crisis. Therefore, the crisis variable is set equal to 1 between 2007 quarter 4 and 2009 quarter 4, and to 0 otherwise. To capture the changes in loan contract terms during the financial crisis, we define the pre-crisis period as 2000-2006, and the post-crisis period as 2010-2012, which enables us to investigate the effects of the financial crisis on loan terms also in the follow-up period.

Any loan contract consists of both price and non-price terms (Melnik \& Plaut, 1986); Strahan (1999) argues that firms pay a higher interest rate when non-price terms become more restrictive. Therefore, we consider both price and non-price terms of syndicated loans as follows. 
Loan spread is an all-in-drawn spread: It displays all spreads at multiple levels based on the margin in basis points and includes the base rate spread and facility, upfront, utilization, or fronting fee in the database. Loan amount in the ThomsonOne database is the full loan package amount for the target market for all tranches and is reported in millions. Loan maturity is another important loan contract term and is measured in years in our study. It is calculated as the difference between the maturity date and the issue date of the loans, where the former is the latest possible maturity date and, if the loan is extendable, the extra years are added to obtain the final maturity, and the issue date for syndicated loans is the announcement date of the transaction. The last loan term considered in the model is the lead arranger. The mandated arrangers are the lead agent banks named in a mandate letter for a particular loan. The mandated arranger title has been in use since January 2000. In Asia, mandated arrangers are the named lead agents in a mandate letter for a particular syndicate and may not be restricted to the administration, syndication, or documentation agents.

Banks assess the creditworthiness of firms before deciding on loan contract terms and focus on several firm-level factors. Therefore, following the literature (e.g., Santos, 2011; Strahan, 1999), we control for firm characteristics. Big firms are assumed to have a lower default probability; therefore, we include firm size, which is defined as the log of total assets. These may need more loans with long maturities for their activities but the spread could be lower than for smaller firms because of the lower default probability. Profitability is measured by the return on assets. Higher return for firms implies less risk from the bank's perspective. More profitable firms may require more loans but may pay less interest as they are considered to be less risky. Older firms are more established and are also viewed as less risky. We capture this by including firm age, which is defined as the log of age. Such firms may obtain more loans with long-term maturity and also pay less interest. Financial leverage is long-term debt over total equity. There is a higher default probability if the firm borrowing is highly debt-dependent, especially during a crisis period. These borrowers may get more loans with a shorter maturity. However, the spread may be higher.

We also include the PE ratio, which is defined as the current price divided by earnings. High growth firms may get more loans with a shorter maturity and a bigger spread. Another variable is EBIT, that is, earnings before interest and tax. Higher earnings suggest a lower default probability. The lead arrangers of a syndicated loan can influence the loan terms with their contribution to the loan (Jones, Lang, \& Nigro, 2005); therefore, we control for the percentage of loans (principle amount) of lead arrangers. The variable share of lead arranger is also included in the model. In the robustness tests, we use additional variables. Most banks check credit ratings. We use Moody's credit rating. According to their generic rating, firms have minimal default risk if they belong to the Aaa category and the risk is higher for categories B and C. Moody's appends numerical modifiers 1, 2, and 3 to each generic rating classification from Aa through Caa. The modifier 1 indicates that the obligation ranks at the higher end of its generic rating category, 2 indicates a mid-range ranking, and 3 a ranking at the lower end of that generic rating category. We also include industry dummy variable, because different industries may be associated with different levels of risks.

\section{2 | Data summary}

Table 1 shows the summary statistics for three categories: domestic syndicated loans (all lead arrangers in a syndicated loan are from China), foreign syndicated loans (at least one lead arranger of a syndicated loan is from a foreign country), and the full sample. The maximum loan amount is 39,000 (US\$, mil), which is for a domestic syndicated loan group. The maximum foreign syndicated loan is 6,000 (US\$, mil); it is arranged by a maximum of 23 lead arrangers, whereas a maximum eight lead arrangers are involved in a domestic syndicated loan.

Table 2 shows the correlation matrix for the variables included in our model. The maturity and loan amount are negatively correlated to the loan spread, and the number of lead arrangers is positively related to the loan spread but negatively related to the loan maturity. Interestingly, the firm size is negatively correlated to the loan spread. This indicates that bigger firms get loans with a lower spread. Diamond (1991) finds that banks provide monitoring and expert advice when they supplies credit to a firm. Banks with higher monitoring ability charge higher spreads and, similarly, highly leveraged firms are likely to be charged higher spreads.

\section{4 | EMPIRICAL RESULTS}

An analysis at the firm level in a cross-sectional setup of the data can only capture the differences between domestic and foreign syndicated loan. Therefore, our paper investigates the changes in loan terms of foreign and domestic syndicated loans over the years in a panel regression framework. In particular, we aim to capture the changes in loan contract terms for both types of syndicated loans during the financial crisis period relative to the other years. Thus, we use a "difference-in-differences" 


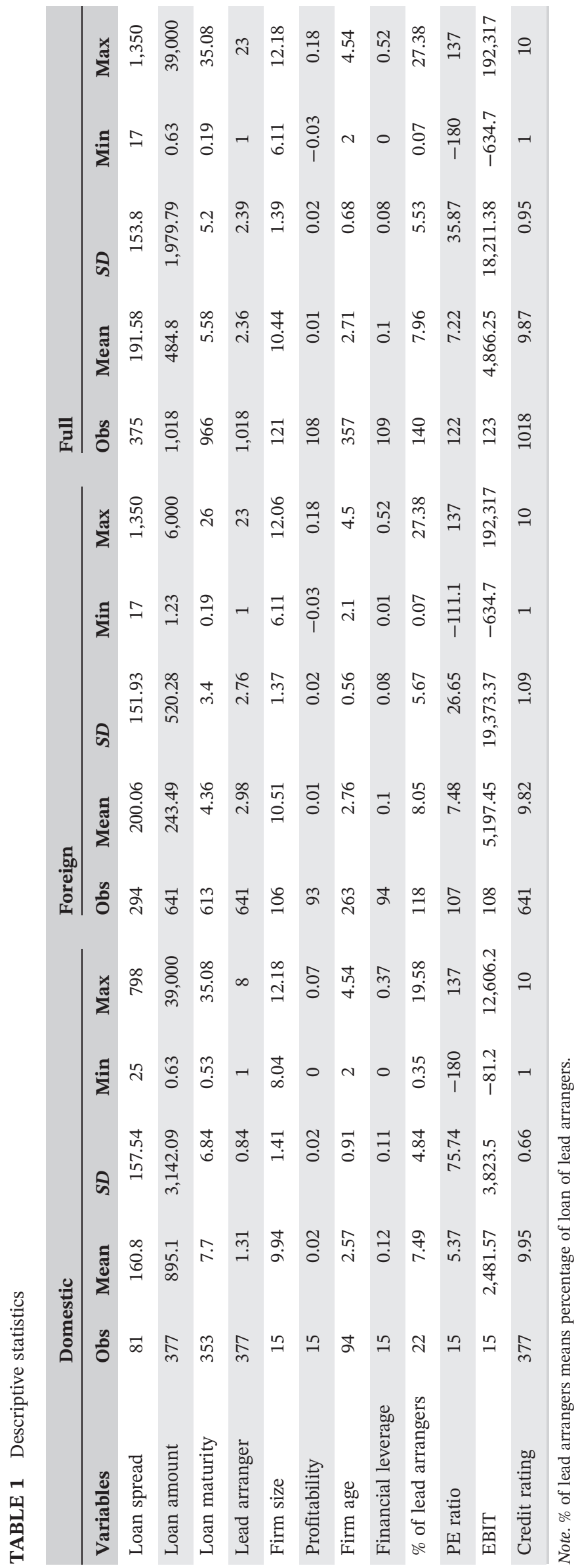


TABLE 2 Correlation matrix

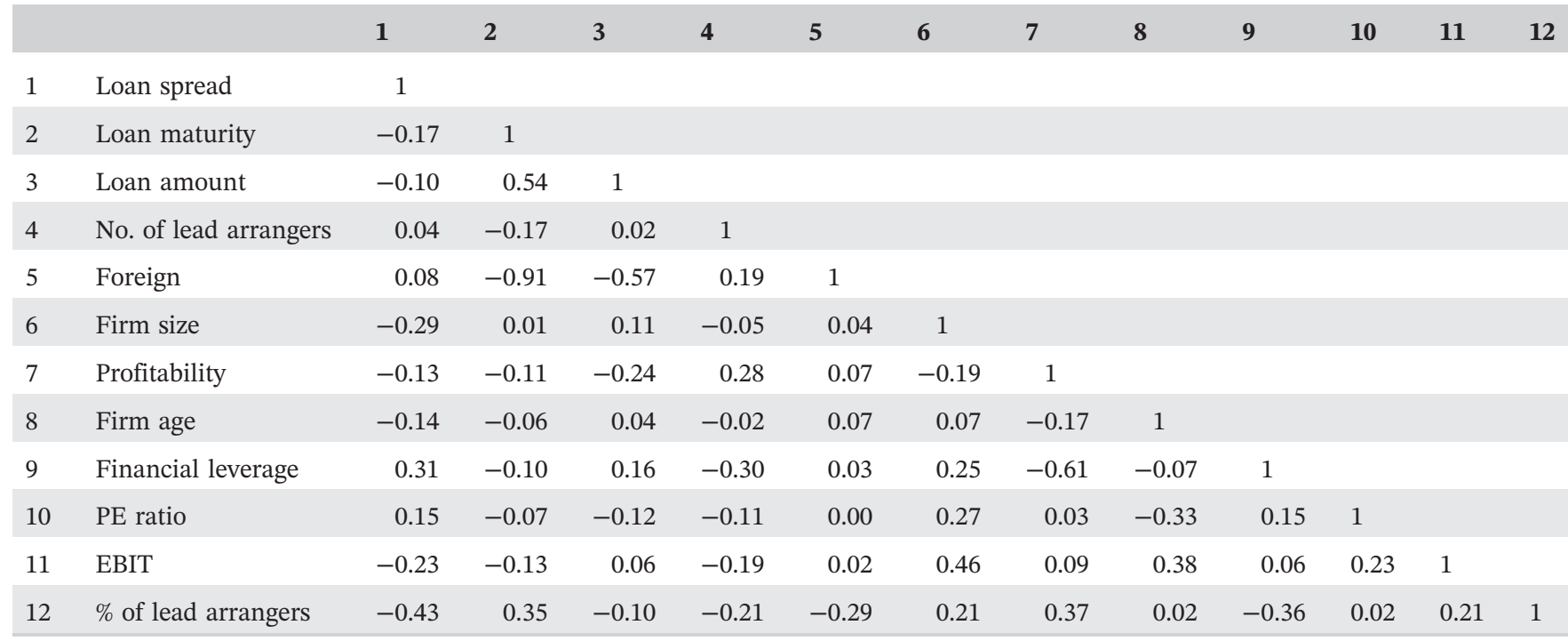

Note. Foreign refers to the foreign syndicated loan defined as those loans when at least one lead arranger of a syndicated loan is from a foreign country.

approach to distinguish between the effects on the loan terms of foreign and domestic syndicated loans of the financial crisis vis-à-vis other financial shocks that also can affect them. In addition, this method enables us to control for time-varying macroeconomic factors. The underlying assumption is that the time trend for the treatment and control groups is the same as in the absence of treatment, which is difficult to verify. Therefore, as a robustness check, we use pre-treatment data to see whether that is actually the case.

\section{1 | Panel data approach (difference-in- differences)}

\subsection{1 | Model}

To examine the impact of the global financial crisis on the price and non-price terms of syndicated loan terms, we estimate the following model:

$$
\begin{aligned}
Y_{i t} & =\alpha_{i}+\beta_{1} \text { Foreign }_{i t}+\beta_{2} \text { Crisis }_{i t} \\
& +\beta_{3} \text { Foreign }_{i t}{ }^{*} \text { Crisis }_{i t}+\beta_{4} \text { FollowUp }_{j t}+\beta_{5} X_{i t} \\
& +\theta_{j}+\varphi_{t}+\in_{i t} \cdots
\end{aligned}
$$

where $Y_{i t}$ indicates the loan spread, loan amount, loan maturity, and number of lead arrangers, respectively, for the $i$ th loan in year $t$ and ${ }_{-i}$ is the firm's fixed effect capturing any time-invariant and unobserved firm characteristic. Following the existing literature, we control for firm size, firm age, leverage, PE ratio, and EBIT (see the previous section for variable definitions). Foreign is a dummy equal to 1 for the treatment group when one or more lead arrangers are from foreign banks and 0 otherwise. Note that in the control group, all the lead arrangers are from
China. Crisis is a dummy equal to 1 if the loan is issued during the period from the fourth quarter of 2007 to the fourth quarter of 2009, and equal to 0 otherwise. We also include three dummies to capture any changes in the follow-up period $(T=2010-2012)$ relative to the crisis period, namely, FollowUp10, FollowUp11, and FollowUp12, each of which is equal to 1 for the corresponding year and 0 otherwise. $X_{i t}$ is the vector of timevarying firm control variables discussed in Section 3.1, ${ }_{-} j$ and ${ }_{-}$are the industry and year fixed effects, and ${ }_{-i t}$ is the error term.

\subsection{2 | Results}

The main results from the regressions using unbalanced panel data are presented in Table 3. In the first two columns, the dependent variable is loan spread. Both regressions include all the explanatory variables. The size variable (log of total assets) is negative in both the columns but statistically significant (at the 5\% significance level) only in the second regression. This suggests that larger banks have lower interest rates. In both regressions, crisis has a positive but statistically insignificant coefficient. There seems to be no economy-wide shock affecting loan spreads related to the financial crisis, which suggests that there was no effect of the financial crisis originating from the developed markets on stateowned banks in China.

In the second regression, we also include an interaction term Foreign*Crisis. If foreign syndicated loan performs differently during the financial crisis period, this interaction term can capture these differences. It has a negative and statistically significant ( $1 \%$ significant level) coefficient, suggesting that foreign syndicated loans have 
TABLE 3 Effects of the financial crisis on syndicated loans

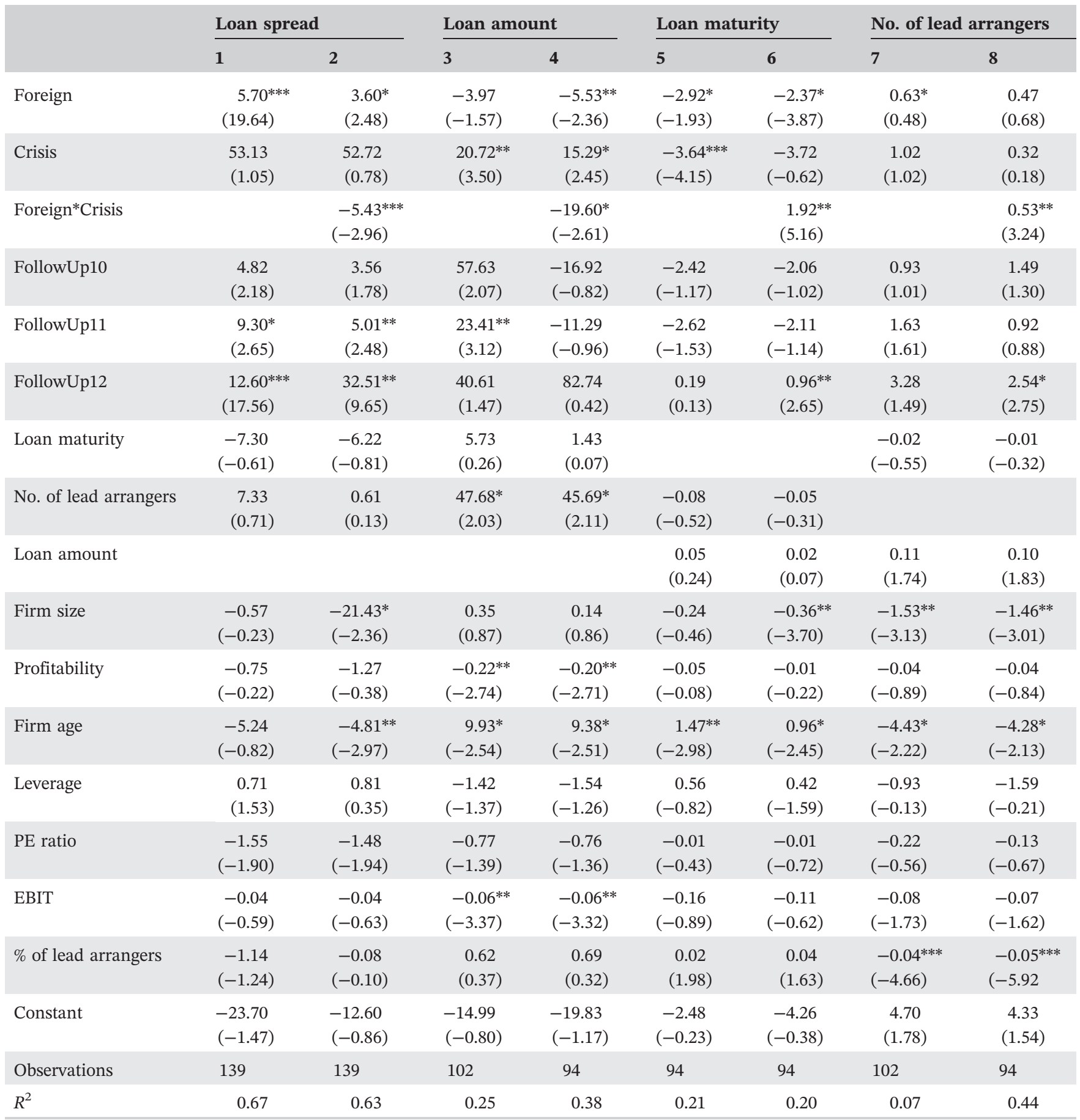

Note. Robust $t$-statistics are in parentheses. The standard errors are obtained using clustering on industry as explained in the methodology. Models are estimated with firm fixed effect.

${ }^{*}$ Coefficients significant at $5 \%$.

**Coefficients significant at $1 \%$.

${ }^{* * *}$ Coefficients significant at $0.1 \%$.

a lower spread during the financial crisis than domestic syndicated loans. This supports Hypothesis 1 .

In the third and fourth regressions, we find that the crisis variable is positive and statically significant at the $1 \%$ and $5 \%$ confidence levels, respectively. This suggests that the loan amount has increased during the financial crisis period, as already mentioned. In the fourth regression, the interaction term has a negative and statistically significant coefficient. This implies that for banks with a foreign lead arranger (dummy variable foreign $=1$ ), the 
loan amount during 2007-2009 (dummy crisis = 1) was lower than in the follow-up period of 2010-2012. Consistently with our prior hypotheses, we find that during the financial crisis, foreign banks became more careful about joining syndicated loans for other countries. Although foreign banks decreased their shares in syndicated loans, domestic banks in China continued to operate effectively: The financial crisis variable has a positive coefficient.

In the fifth and sixth regression, we use loan maturity as the dependent variable. The coefficient on the crisis variable is negative, and statistically significant (at the $1 \%$ level) in the fifth regression but insignificant in the sixth regression. This indicates that during the financial crisis loan maturity became shorter in the presence of greater uncertainty. The interaction term in the sixth regression is positive and statistically significant, which suggests that foreign syndicated loans have longer maturity than domestic syndicated loans, and this also holds for the follow-up period. This supports our Hypothesis 3. The Chinese market was stable during the crisis and foreign banks experienced less risk compared with other countries including their own. Moreover, as a result of financial market and banking reforms in China, the improved credit scoring reduced uncertainty about borrowers (see Berger, Espinosa-Vega, Scott Frame, \& Miller, 2005, Berger, Miller, Petersen, Rajan, \& Stein, 2005).

In our last set of regressions, we use the number of lead arrangers as the dependent variable. The interaction term has a positive and statistically significant coefficient (see the last column of Table 3). A plausible explanation is that the demand for syndicated loans in China remained the same or increased during the financial crisis and the loan amount from foreign banks decreased, and the number of lead arrangers increased to meet demand. In other words, during the financial crisis (2007-2009), the number of lead arrangers increased for the foreign syndicated loans to diversify risk and to compensate capital inadequacy in their home country. It also appears that there was a $20 \%$ increase in foreign lead arrangers in the follow-up period of 2012 (coefficient $=2.54$, significant $5 \%$ significance level). This supports our Hypothesis 4.

\section{2 | Discussions on the findings in the follow-up period}

Columns 1 and 2 of Table 3 show that the coefficients of FollowUp11 and FollowUp12 are positive and significant. Presumably from 2011, when the financial markets of the developed countries started improving, the foreign lead arrangers found ways to recover their financial position in their domestic markets. Moreover, during the crisis, they established good relationships ("guanxi" or personal relationships or networks) with the Chinese borrowers, and to compensate their low spread during the crisis increased interest rates in the post-crisis period. In the second set of regressions, where the loan amount is the dependent variable, we do not find any significant changes (except for the year 2011 in column 3) in the follow-up period. We interpret this result as suggesting that the total amount of loans remained unchanged owing to the more active involvement of domestic banks in China as the focus of foreign banks shifted to their domestic markets. This is consistent with previous findings (Chui et al., 2010).

Interestingly, firm age is negatively related to the loan spread and positively related to the loan amount. This shows that since over the years Chinese firms develop good relationship with banks, the older firms are likely to get better loan terms compared with younger firms. The leverage variable is negatively related to the loan amount and the number of lead arrangers, but is not significant - the debt overhang problem of firms has adverse effect on the loan contract decision of banks (regardless of whether the banks are state-owned or not).

Overall, we find empirical support for the hypotheses formulated above. During the financial crisis, foreign syndicated loans decreased despite a higher number of lead arrangers and longer maturities. However, to cope with the imbalances in the global economy and the credit market crunch, the foreign syndicated loan providers kept lower spreads by diversifying their risk through a number of lead arrangers.

\section{3 | Robustness tests}

Next we check the sensitivity of our main results on the existence of flight to quality (or banks' response to heterogeneity of borrowers) during the financial crisis, in particular after the Lehman Brothers' collapse. The results of the robustness tests are reported in Table 4. First we consider an alternative definition of the crisis period. Because the financial crisis was at its peak in the fourth quarter of 2008 , we define crisis as a dummy equal to 1 if the loan is announced between the fourth quarter of 2008 and the fourth quarter of 2009 and 0 otherwise. In this revised set-up, we exclude the borrowers with $\$ 200,000$ mil USD market capitalization (there are 19 of them) and estimate the model again by the difference-in-differences method. The coefficients are reported in Panel A of Table 4. The results are qualitatively the same as the main ones displayed in Tables 3 .

We then select firms on the basis of their credit rating. We exclude firms with rating Aa2, A2, and A3 (top rating grades with A's in our sample). These are the firms with the lowest default rate, that is, the lowest risk. We re- 
TABLE 4 Robustness tests

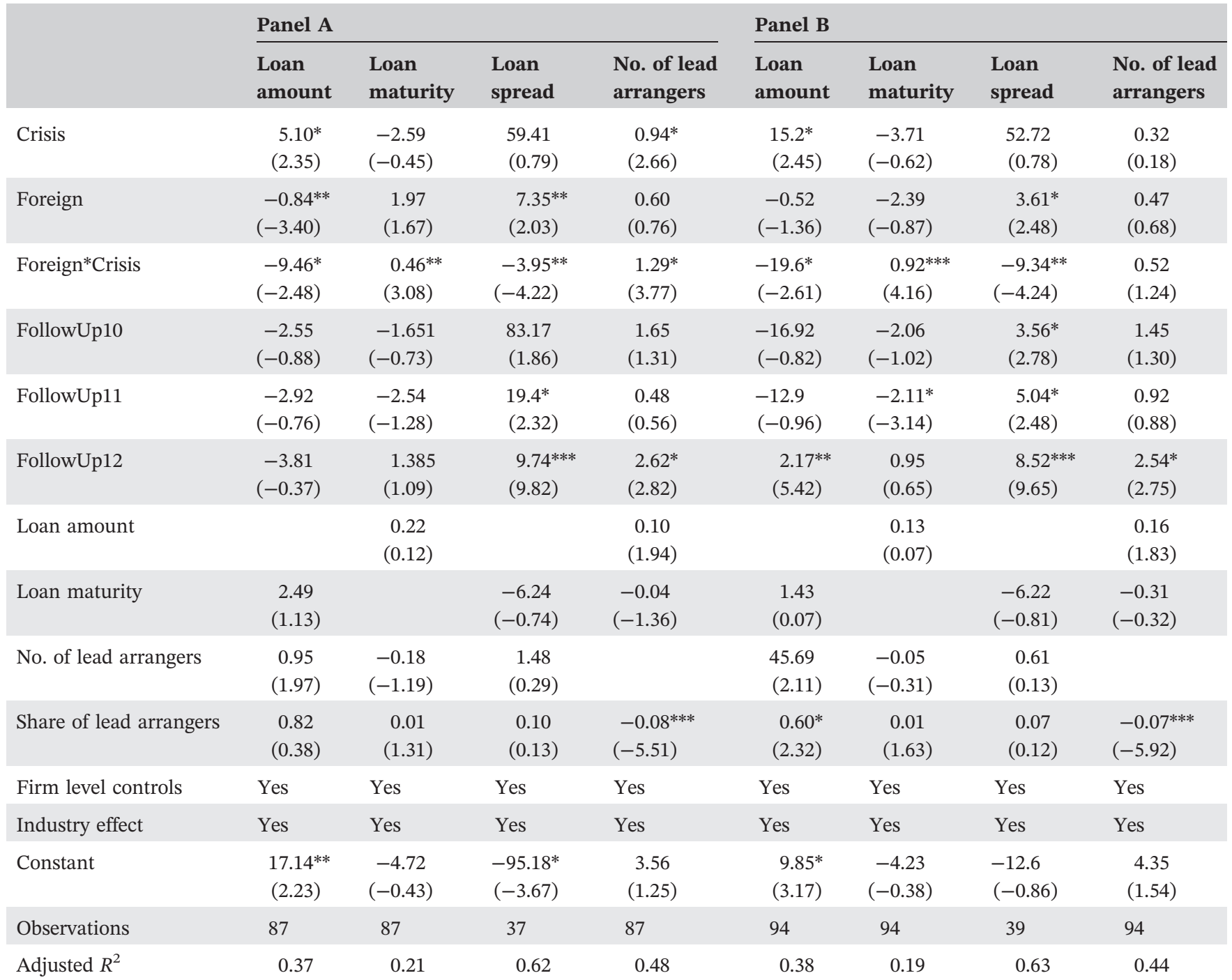

Note. In Panel A, we exclude those borrowers, which have the highest market capitalization (top 25\%). In Panel B, we exclude all the firms that have Moody's rating Aa2, A2, and A3. Models are estimated by clustering at the industry level with block bootstrapping standard errors. In all models, firm level controls, such as firm size, financial leverage, profitability and price-earnings ratio (in 1-year lag), and firm age, are included.

*Coefficients significant at $5 \%$.

${ }^{* *}$ Coefficients significant at $1 \%$.

$* * *$ Coefficients significant at $0.1 \%$

estimate the model in this case (with foreign syndicated loans only offered to the less risky borrowers in the Chinese market to reduce their risk of default) and find again that the main results are robust (see Panel B of Table 4). Therefore, we conclude that during the financial crisis, the foreign syndicated loan arrangers targeted the entire Chinese market, irrespective of the borrowers' risk. This is also evident from our finding that foreign syndicated loans have flexible loan contract terms, such as lower spread and longer maturity.

Table 4 reports the estimation results by clustering at the industry level. In order to ascertain whether both foreign and domestic syndicated loans have a similar time trend in the absence of a financial market meltdown, we also estimate the model with firm fixed effects using the pre-treatment data (these results are not reported). Bertrand, Duflo, and Mullainathan (2004) show that the conventional standard errors often understate the standard deviation of the diff-in-diff estimators; therefore, we compute block bootstrapping standard errors. As we do not have the same information set as the lenders, we cannot check whether Basel II risk-sensitive capital requirement effects drive our results. A future study could investigate this issue.

We also explore the effects of the financial crisis on the aggregate loan spread-maturity, loan spread-amount, and loan amount-maturity relationships. A simple correlation analysis would not be sufficient for this purpose; 
we use instead Engle's (2002) time-varying dynamic conditional correlation-GARCH model (these results are available on request). Figure 1 plots the dynamic correlation between loan amount and loan spread of foreign syndicated loans. It clearly shows that the entry of foreign banks into China peaked in 2005. During the crisis period (2007-2009), foreign syndicated loans and spread fluctuated. In particular, Kalman filtering shows a sharp fall of their correlation in the fourth quarter of 2008 (see Figure 2).

Owing to the very robust growth of the economy, the corporate sector in China required diversified channels of funding, stable and strong credit growth, and interest rate reforms. Interestingly, during 2000-2007, the share of assets held by foreign banks rose with a peak of above $2 \%$, but as a result of the financial crisis, it fell to 1.75\% (Global Financial Development Database, 2013 http://www.worldbank.org/en/publication/gfdr/data/ global-financial-development-database). This can be seen in Figure 3.

Figure 4 shows the dynamic correlation between foreign syndicated loan amount and maturity; this fluctuated widely during the financial crisis; it peaked at 0.78 in August 2008 and fell as low as 0.3 in July 2009.

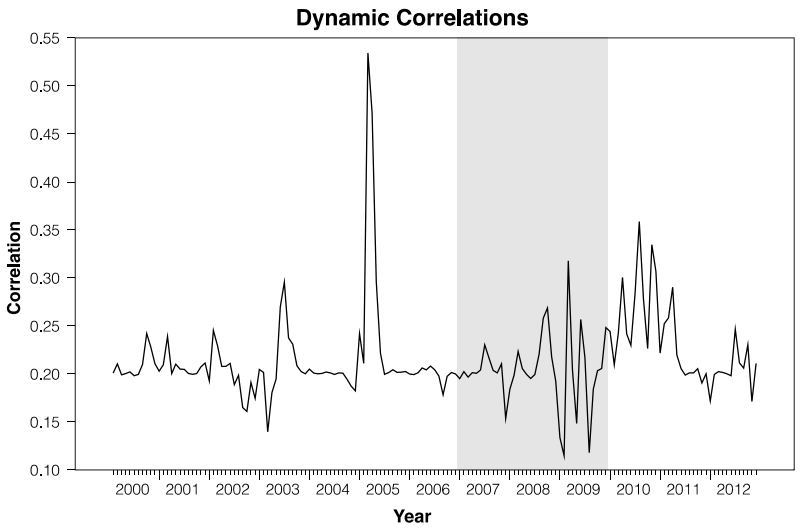

FIGURE 1 Foreign syndicated loan amount and spread

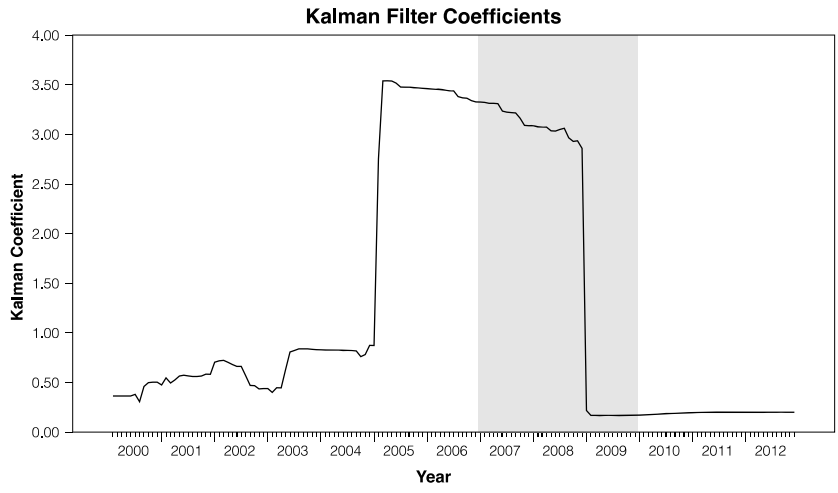

FIGURE 2 Kalman estimates on correlation of foreign syndicated loan amount and loan spread

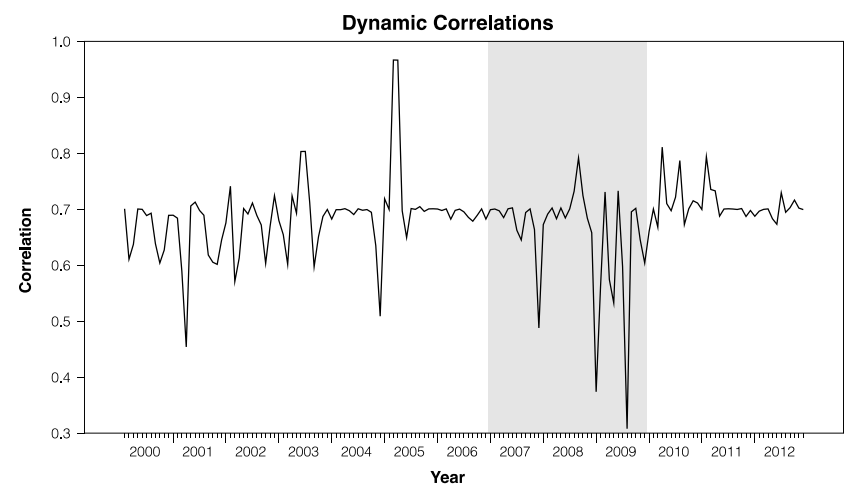

FIGURE 3 Foreign syndicated loan maturity and spread

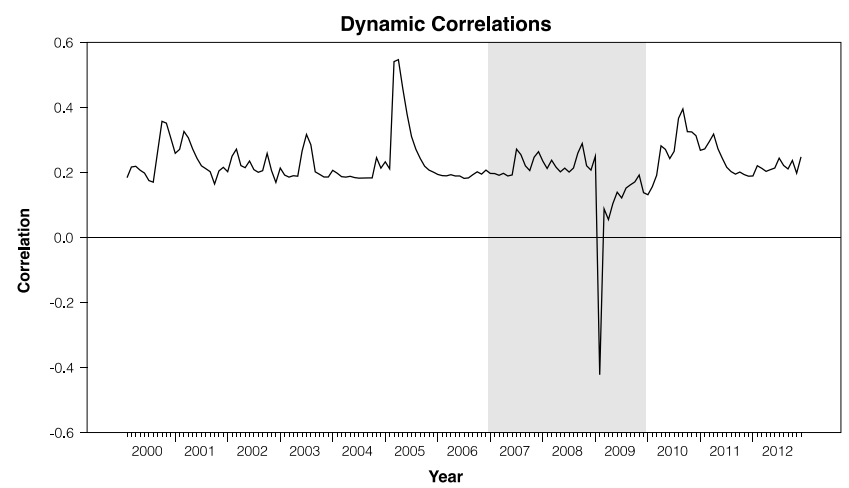

FIGURE 4 Foreign syndicated loan amount and maturity

\section{5 | CONCLUSIONS}

The importance of syndicated loans in the corporate debt market has been highlighted in both the theoretical and empirical literature. During the global financial crisis, their volume was squeezed in most countries (Ivashina \& Scharfstein, 2010), and banks from the developed countries quit the emerging markets (Chava \& Purnanandam, 2011). It seems that dysfunctional securitization markets have limited these banks to place syndicated loans in the secondary market. In China, however, the financial reforms implemented before the crisis enabled domestic banks and financial institutions to play a bigger role in the syndicated loan market. As a result, the volume of syndicated loans in China grew steadily during the crisis (Chui et al., 2010).

The present paper examines not only lending volumes but also the cost of debt and more generally both the price and non-price terms of syndicated loans. The analysis reveals that foreign syndicated loans offered lower interest rates to attract more Chinese borrowers. Moreover, the loan amount was lower for longer maturities in the case of foreign syndicated loans in China. Domestic syndicated loan arrangers tended to offer better non-price 
than price terms. This has resulted in a constant credit supply in China during the global financial crisis. In addition, the increased number of foreign lead arrangers for syndicated loans during the financial crisis represents clear evidence of the effects of financial reforms and suggests almost no informational asymmetries between foreign and domestic banks.

Our findings contribute to the literature on crossborder syndicated loans and on syndicated loans in emerging economies during financial crises. Information on banks' lending volumes in emerging markets is not sufficient to design policy responses to financial crises; the amount and cost of debt should also be examined. Our study of the Chinese case suggests that the impact of the financial crisis in emerging markets was mitigated by appropriate syndicated loan contract terms and that a greater involvement of foreign banks contributed to the financial development of China.

This evidence has important policy implications: If indeed the poor institutional framework in China and similar emerging markets limited the foreign syndicated loan issuance, measures favouring the participation of foreign banks should be taken to reduce legal obstacles (in particular, state government's intervention in financial system). Our findings are also relevant for policy makers of other emerging countries aiming to design an effective debt market strategy to tackle future global crises, because bank credit has a significant impact not only on firms' activities but also on the macroeconomy (Campello, Graham, \& Harvey, 2010). A follow-up study will investigate such effects in the post-crisis period; other interesting topics for future research are creditors' corporate governance and the lending structure in emerging markets during financial crises in a multi-country scenario.

\section{ORCID}

\section{Guglielmo Maria Caporale (D) http://orcid.org/0000-0002- 0144-4135}

\section{REFERENCES}

Ahlstrom, D., Young, M. N., Nair, A., \& Law, P. (2003). Managing the institutional environment: Challenges for foreign firms in postWTO China. SAM Advanced Management Journal, 68, 41-49.

Alexandre, H., Bouaiss, K., \& Refait-Alexandre, C. (2014). Banking relationships and syndicated loans during the 2008 financial crisis. Journal of Financial Services Research, 46(1), 99-113.

Altunbas, Y., \& Gadanecz, B. (2004). Developing country economic structure and the pricing of syndicated credits. Journal of Development Studies, 40, 143-173.

Baileya, W., Huanga, W., \& Yanga, Z. (2011). Bank loans with Chinese characteristics: Some evidence on inside debt in a state-controlled banking system. Journal of Financial and Quantitative Analysis, 46(6), 1795-1830.

Bartoli, F., Ferri, G., Murroc, P., \& Rotondi, Z. (2013). Bank-firm relations and the role of Mutual Guarantee Institutions at the peak of the crisis. Journal of Financial Stability, 9, 90-104.

Beltratti, A., and Stulz, R.M., (2009). Why did some banks perform better during the credit crisis? A cross-country study of the impact of governance and regulation. NBER Working Paper 15180.

Berger, A. N., \& Bouwman, C. H. S. (2013). How does capital affect bank performance during financial crises? Journal of Financial Economics, 109(1), 146-176.

Berger, A. N., DeYoung, R., Flannery, M. J., Lee, D., \& Oztekin, O. (2008). How do large banking organizations manage their capital ratios? Journal of Financial Services Research, 34(2-3), 123-149.

Berger, A. N., Espinosa-Vega, M. A., Scott Frame, W., \& Miller, N. H. (2005). Debt maturity, risk and asymmetric information. Journal of Finance, 60(6), 2895-2923.

Berger, A. N., Hasan, I., \& Zhou, M. (2010). The effects of focus versus diversification on bank performance: Evidence from Chinese banks. Journal of Banking \& Finance, 34, 1417-1435.

Berger, A. N., Miller, N. H., Petersen, M. A., Rajan, R. G., \& Stein, J. C. (2005). Does function follow organizational form? Evidence from the lending practices of large and small banks. Journal of Financial Economics, 76(2), 237-269.

Bertrand, M., Duflo, E., \& Mullainathan, S. (2004). How much should we trust differences-in-differences estimates? Quarterly Journal of Economics, 119(1), 249-275.

Bonaccorsi di Patti E, and Sette, E. 2012. Bank balance sheets and the transmission of financial shocks to borrowers: Evidence from the 2007-2008 crisis. Bank of Italy Temi di Discussione, Working Paper, No. 848.

Bord, V. M., \& Santos, J. A. C. (2014). Banks' liquidity and the cost of liquidity to corporations. Journal of Money, Credit and Banking, 46(s1), 13-45.

Brealey, R. A., Cooper, I. A., \& Habib, M. A. (1996). Using project finance to fund infrastructure investments. Journal of Applied Corporate Finance, 9, 25-38.

Bruche, M., \& Llobet, G. (2014). Preventing zombie lending. Review of Financial Studies, 27(3), 923-956.

Bruno, V., \& Hauswald, R. (2014). The real effect of foreign banks. Review of Finance, 18(5), 1683-1716.

Campello, M., Graham, J. R., \& Harvey, C. R. (2010). The real effects of financial constraints: Evidence from a financial crisis. Journal of Financial Economics, 97, 470-487.

Cetorelli, N., \& Goldberg, L. S. (2011). Global banks and international shock transmission: Evidence from the crisis. IMF Economic Review, 59, 41-76.

Cetorelli, N., \& Goldberg, L. S. (2012). Banking globalization and Monetary Transmission. The Journal of Finance, 67(5), 1811-1843.

Chava, S., \& Purnanandam, A. (2011). The effect of banking crisis on bank-dependent borrowers. Journal of Financial Economics, 99, 116-135.

Chodorow-Reich, G. (2014). The employment effects of credit market disruptions: Firm-level evidence from the 2008-2009 financial crisis. Quarterly Journal of Economics, 129, 1-59. 
Chui, M., Domanski, D., Kugler, P., and Shek, J., (2010). The collapse of international bank finance during the crisis: Evidence from syndicated loan markets. BIS Quarterly Review Sep: 39-49.

Claessens, S., \& Van Horne, N. (2014). Foreign Banks: Trends and Impact. Journal of Money, Credit and Banking, 46(S1), 295-326.

Claessens, S., \& Van Horne, N. Foreign Banks: Trends, Impact and Financial Stability (December 28, 2011). De Nederlandsche Bank Working Paper No. 330. Available at SSRN: https://ssrn.com/ abstract $=1977446$ or http://doi.org/10.2139/ssrn.1977446

Coleman, A. D. F., Esho, N., \& Sharpe, I. G. (2006). Does bank monitoring influence loan contract terms. Journal of Financial Services Research, 30(2), 177-198.

De Haas, R., \& Van Horen, N. (2012). International shock transmission after the Lehman Brothers collapse: Evidence from syndicated lending. American Economic Review, 102(3), 231-237.

Demirguc-Kunt, A., Detragiache, E., \& Merrouche, O. (2013). Bank capital: Lessons from the financial crisis. Journal of Money, Credit and Banking, 45, 1147-1164.

Dennis, S., \& Mullineaux, D. J. (2000). Syndicated loans. Journal of Financial Intermediation, 9, 404-426.

Diamond, D. W. (1991). Monitoring and reputation: The choice between bank loans and directly placed debts. Journal of Political Economy, 99(4), 689-721.

Diamond, D. W. (2004). Committing to commit: Short-term debt when enforcement is costly. AFA Presidential Address. Journal of Finance, 59, 1447-1480.

Doverna, J., \& Royeb, B. V. (2014). International transmission and business-cycle effects of financial stress. Journal of Financial Stability, 13, 1-17.

Drucker, S., \& Puri, M. (2007). Banks in capital markets: A survey. In Empirical Corporate Finance. In E. Eckbo (Ed.), Handbooks in finance (pp. 189-232). Amsterdam: Elsevier/North-Holland Publishers.

Engle, R. (2002). Dynamic conditional correlation: A simple case of multivariate generalized autoregressive conditional heteroskedasticity models. Journal of Business \& Economic Statistics, 20(3), 339-350.

Ferreira, M. A., \& Matos, P. (2012). Universal banks and corporate control: Evidence from the global syndicated loan market. Review of Financial Studies, 25(9), 2703-2744.

Focarelli, D., Pozzolo, A. F., \& Casolaro, L. (2008). The pricing effect of certification on syndicated loans. Journal of Monetary Economics, 55, 335-349.

Giannetti, M., \& Laeven, L. (2012). The flight home effect: Evidence from the syndicated loan market during financial crises. Journal of Financial Economics, 104(1), 23-43.

Global Financial Development Database. (2013). http://www. worldbank.org/en/publication/gfdr/data/global-financial-development-database

Godlewski, C. J., \& Weill, L. (2008). Syndicated loans in emerging markets. Emerging Markets Review, 9, 206-219.

Gottesman, A. A., \& Roberts, G. S. (2004). Maturity and corporate loan pricing. Financial Review, 38, 55-77.
Hasan, I., Wachtel, P., \& Zhou, M. (2009). Institutional development, financial deepening and economic growth: Evidence from China. Journal of Banking \& Finance, 33, 157-170.

Houston, J. F., \& James, C. (1998). Do bank internal capital markets promote lending. Journal of Banking and Finance, 22(6-8), 899-918.

Ivashina, V., \& Scharfstein, D. S. (2010). Bank lending during the financial crisis of 2008. Journal of Financial Economics, 97, 319-338.

Ivashina, V., \& Scharfstein, D. S. (2010a). Loan syndication and credit cycles. American Economic Review: Papers and Proceedings, 100(2), 1-8.

Jia, C. (2009). The effect of ownership on the prudential behavior of banks-The case of China. Journal of Banking \& Finance, 33, 77-87.

Jiangli, W., Unal, H., \& Yom, C. (2008). Relationship lending, accounting disclosure, and credit availability during the Asian financial crisis. Journal of Money, Credit and Banking, 40(1), 25-55.

Jones, J., Lang, W. W., \& Nigro, P. J. (2005). Agent bank behavior in bank loan syndications. Journal of Financial Research, 28(3), 385-402.

Lee, S. W., \& Mullineaux, D. J. (2004). Monitoring, financial distress, and the structure of commercial lending syndicates. Financial Management, 107-130.

Liang, X., Lu, X., \& Wang, L. (2012). Outward internationalization of private enterprises in China: The effect of competitive advantages and disadvantages compared to home market rivals. Journal of World Business, 47(1), 134-144.

Liberti, J. M. (2005). How does organizational form matter? Northwestern, Chicago IL: Working paper, Kellogg School of Management.

Melnik, A., \& Plaut, S. (1986). Loan commitment contracts, terms of lending, and credit allocation. Journal of Finance, 41, 425-435.

Mishkin, F. S. (2009). Is Monetary Policy Effective During Financial Crises? NBER Working Paper No. 14678.

Murali, D. R. C., \& Banalieva, E. R. (2015). How do pro-market reforms impact firm profitability? The case of India under reform. Journal of World Business, 50, 357-367.

Nandy, M., \& Lodh, S. (2012). Do banks value the eco-friendliness of firms in their corporate lending decision? Some empirical evidence. International Review of Financial Analysis, 25, 83-93.

Okazaki, K., (2007). Banking system reform in China the challenges of moving toward a market-oriented economy. RAND/OP-194CAPP.

Panizza, U., \& Presbitero, A. F. (2014). Public debt and economic growth: is there a causal effect? Journal Macroeconomics, 41, 21-41.

Pennacchi, G. (1988). Loan sales and the cost of bank capital. Journal of Finance, 43(2), 375-396.

Pessarossi, P., \& Weill, L. (2013). Choice of corporate debt in China: The role of state ownership. China Economic Review, 26, 1-16.

Papov, A., \& Udell, G. (2012). Cross-border banking, credit access, and the financial crisis. Journal of International Economics, 87(1), 147-161. 
Popov, A., \& Van Horen, N., (2013). The impact of sovereign debt exposure on bank lending: Evidence from the European debt crisis, DNB Working paper. No. 382 June.

Rajan, R. G. (1992). Insiders and outsiders: The choice between informed and arm's-length debt. Journal of Finance, 47, 1367-1400.

Santos, J. A. C. (2011). Bank corporate loan pricing following the subprime crisis. Review of Financial Studies, 24(6), 1916-1943.

Stein, J. C. (2002). Information production and capital allocation: Decentralization versus hierarchical firms. Journal of Finance, 57(5), 1891-1921.

Strahan, P. E., (1999). Borrower risk and the price and non-price terms of bank loans. Working Paper.

Sufi, A. (2007). Information asymmetry and financing arrangements: Evidence from syndicated loans. Journal of Finance, 62, 629-668.
Young, M. N., Ahlstrom, D., Bruton, G. D., \& Rubanik, Y. (2011). What do firms from transition economies want from their strategic alliance partners? Business Horizons, 54(2), 163-174.

Young, M. N., Tsai, T., Wang, X., Liu, S., \& Ahlstrom, D. (2014). Strategy in emerging economies and the theory of the firm. Asia Pacific Journal of Management, 31(2), 331-354.

How to cite this article: Caporale GM, Lodh S, Nandy M. How has the global financial crisis affected syndicated loan terms in emerging markets? Evidence from China. Int J Fin Econ. 2018;23:478-491. https://doi.org/10.1002/ijfe.1633 